This is an electronic reprint of the original article. This reprint may differ from the original in pagination and typographic detail.

Author(s): Lähdesmäki, Tuuli

Title: The Problematic of Conceptualizing a European Cultural Heritage

Year: $\quad 2016$

Version:

Please cite the original version:

Lähdesmäki, T. (2016). The Problematic of Conceptualizing a European Cultural Heritage. In N. Johnson, \& S. Simpson (Eds.), Bridging Differences : Understanding Cultural Interaction in Our Globalized World (pp. 65-79). Inter-Disciplinary Press. https://doi.org/10.1163/9781848883680_007

All material supplied via JYX is protected by copyright and other intellectual property rights, and duplication or sale of all or part of any of the repository collections is not permitted, except that material may be duplicated by you for your research use or educational purposes in electronic or print form. You must obtain permission for any other use. Electronic or print copies may not be offered, whether for sale or otherwise to anyone who is not an authorised user. 


\title{
The Problematic of Conceptualizing a European Cultural Heritage
}

\author{
Tuuli Lähdesmäki
}

\begin{abstract}
The idea of a common European cultural heritage is frequently referred to in the political discourses and practices of the EU. The idea of a European cultural heritage elevates the ideas of ownership and inheritance beyond the local, regional, or national frameworks and transforms the heritage sites and objects into a 'common good' belonging to all Europeans and into a source of a common European cultural identity. Scholars have debated the possibility of a common European cultural heritage, and in case such could exist, what it could be grounded upon. Critical scholars have asked what might be the trans-border European dimension of heritage that goes beyond the mere sum of national, regional, or local icons, or questioned the possibility of common European heritage practices due to the lack of a singular European people. Some scholars have, however, found a possible common ground for a European cultural heritage for example in urbanity, European cities and their historical environment, and the styles and movements of art and architecture. Functions and uses of the idea of European cultural heritage and the contexts in which it becomes important and meaningful have changed over the course of time and are constantly transforming. The recent societal, political, and cultural changes in Europe have influenced the notions on heritage and made the concept of a common European cultural heritage more problematic. What is a European cultural heritage and how has it been approached in recent scholarly discussions? How can a European cultural heritage be made sense of in relation to the ideas of universalism, cosmopolitanism, particularism, transnationalism, translocalism, transculturalism, and pan-Europeanism? The paper aims to clarify the meanings of a European cultural heritage and critically discuss the problematic related to its foundations.
\end{abstract}

Key Words: Cosmopolitanism, European cultural heritage, particularism, scholarly discussion, transculturalism, translocalism, transnationalism, universalism.

\section{$* * * * *$}

\section{Introduction: What Constitutes a European Cultural Heritage?}

Cultural heritage is an emotionally charged concept through which people make sense of the past and fix various cultural and social meanings in the present. For many people, it betokens inherited customs and a sense of accumulated communal experiences, and is, therefore, often used to describe a set of shared values and collective memories. ${ }^{1}$ Cultural heritage is a means to manifest cultural 
belonging, communality, and identity. During the past two centuries, these communal meanings of cultural heritage have been commonly fixed to nations. The concept of cultural heritage is inseparable from the emergence of the idea of national cultures and the development of nation-states. ${ }^{2}$ Many of the institutions through which cultural heritage is still being preserved and promoted played a crucial role in the 19th century nation-building processes. ${ }^{3}$ In addition to the national framework, cultural heritage has also been approached from universalistic points of view which consider it the common property of mankind and the shared legacy of civilizations. For example, the UNESCO World Heritage List is based on this kind of universalistic understanding of the value of heritage. Nationalist and universalistic notions on cultural heritage are challenged when the idea of heritage is fixed to a continent.

The trans-border dimensions of cultural heritage have recently become topical in Europe in a new way: the idea and concept of a common European cultural heritage have been more and more frequently referred to in the political discourses and practices of the EU. In addition, the concept has often been used in scholarly discussions on the EU and Europe. The concept of a European cultural heritage elevates the ideas of ownership and inheritance beyond the local, regional, or national values and transforms the heritage sites and objects into a 'common good' belonging to all Europeans and into a source of a common European cultural identity. The recent societal, political, and cultural changes in Europe, such as the rise of neo-nationalism and the diversification of European societies, have influenced the notions on heritage and made the concept of a common European cultural heritage more problematic.

What is a European cultural heritage and how has it been approached in recent scholarly discussions? How does a European cultural heritage make sense in relation to the ideas of universalism, cosmopolitanism, particularism, transnationalism, translocalism, transculturalism, and pan-Europeanism? The paper aims to clarify the meanings of a European cultural heritage and critically discuss the problematic related to its foundations.

\section{Cosmopolitanist versus Particularist Views}

The relations between ownership and communal values of cultural heritage have been much debated both in scholarly discussions and among cultural officials, policy makers, and heritage administrators. Some significant museum objects which have been transported from other countries or continents to major European collections and museums during the past centuries have regularly caused discussion regarding to whom this cultural heritage belongs and how the idea of ownership of heritage should be approached. On a general level, these discussions can be perceived as promoting two views. John Merryman has identified these views as 'cultural internationalism' and 'cultural nationalism'. ${ }^{4}$ The former view, which Merryman describes as cosmopolitan, perceives cultural property as a 
component of common human culture, whatever their places of origin or present location, independent of property rights or national jurisdiction. The other approaches cultural property as a part of national cultural heritage. It gives nations a special interest, implies the attribution of national character to objects independently from their location or ownership, and legitimizes national export controls and demands for the 'repatriation' of cultural property. Merryman states that the view of 'cultural nationalism' has not only dominated the national forums and literature on cultural property but also provided the reigning terms of discourse in the UNESCO and other international heritage organizations. ${ }^{5}$ Although several scholars have emphasized the way UNESCO fosters universalistic discourse in its policy rhetoric, ${ }^{6}$ since e.g., the labelling criteria of the UNESCO World Heritage List require that the objects have 'outstanding universal value', ${ }^{7}$ the conventions of the UNESCO, however, recognize the national ownership of cultural property and national legislation over heritage protection. ${ }^{8}$

The internationalist and nationalist - or cosmopolitanist and particularist views to cultural heritage have a long history reaching all the way back to the 18th century. The cosmopolitanist view was commonly emphasized by the intellects of the Enlightenment, who perceived (European) cultural ideas and assets as having value for the universal community of citizens. Collecting cultural objects was considered as a means to measure, order, and grasp the world. The educational attempts related to the mindset of Enlightenment gave rise to a new type of institution: the public museum. As opposed to the cosmopolitanist notion on cultural heritage, the movement of romantic nationalism emphasized a particularist relation between culture, place, time, and communities: the idea of cultural heritage was fixed to a nation and places belonging to national self-understanding. Since then, these different views have also often been promoted as entwined. ${ }^{9}$ Derek Gillman suggests a mediating position between the strong versions of cosmopolitanist and particularist views. According to him, a liberalist position, which appreciates both the cosmopolitan approach while acknowledging the individual's social dependence and attachments to communities, functions as an attempt to balance between the two opposing views on cultural heritage. ${ }^{10}$

During the 1990s, cosmopolitanism became an increasingly important dimension of European self-understanding. ${ }^{11}$ The idea of a cosmopolitan Europe was developed in a range of academic and political analyses. The analyses and their results reflect the diversity of perspectives from which the concept of cosmopolitanism has been discussed in recent scholarly literature. As Bruce Robbins notes, the meanings and contents of cosmopolitanism and cosmopolitics have drastically changed in the globalized world in the end of the 20th century. ${ }^{12}$

The traditional notion on cosmopolitanism has claimed universality by virtue of its independence and detachment from the bonds, commitments, and affiliations that were perceived as constraining nation-bound lives. The cosmopolitan thoughts of the past represented a privileged free-floating view from 'above'. During the 
past decades, various scholars have broadened the concept of cosmopolitanism by including into it transnational experiences which are particular rather than universal, and which are unprivileged. Global flows of transnational cultural traffic have produced postcolonial cosmopolitanism, as Benita Parry notes. ${ }^{13}$ In recent literature, these kinds of takes on cosmopolitanism have been described, e.g., as 'vernacular ${ }^{14}$ or 'rooted'. ${ }^{15}$ These points of view criticize the Eurocentric ethos of cosmopolitanism and its 'cosmopolitanism from above', choosing to emphasize a 'cosmopolitanism from below': peoples in diaspora, refugees, migrants, traders, artisans, pilgrims, friends made on the road - and their cosmopolitan experiences, practices and identification in various and changing local and regional contexts. ${ }^{16}$ In addition, Kwame Anthony Appiah stresses cosmopolitanism and patriotism, or cosmopolitanism and regionalism, as coexistent phenomena. From his point of view, these sentiments are not exclusive: one can have roots embedded in a specific regional or national history and still conceive of oneself in terms of global identities or universal values. ${ }^{17}$

Although current points of view stress the multicentric character of cosmopolitanism, it still often includes discourses which are produced from above and reflecting Eurocentric and Western standards. As Jan Nederveen Pieterse notes, cosmopolitanism does not always follow its ideals: while claiming universality, it reflects a regional and parochial order. ${ }^{18}$ According to him, parochialism dressed up as universalism is well-established in relation to the Enlightenment, progress, civilization, rationality, modernity, liberalism, democracy, development, human rights, good governance, etc. ${ }^{19}$ Parochial (Eurocentric or Western) norms are often elevated to general norms. Similarly, Craig Calhoun stresses that cosmopolitanism is neither neutral nor universal. He points out that contemporary cosmopolitanism still commonly reflects the experiences and perspective of elites and obscures the social foundations on which that experience and perspective rest. ${ }^{20}$

\section{Transnational and Translocal Views}

Transnationalism is often perceived as heightened interconnectivity between people, assets, and culture and the receding economic and social significance of boundaries among nation-states. The idea of transnational cultural heritage broadens the particularistic view but does not, however, extend the meanings of heritage to the universal level. While the universalistic and cosmopolitanist views to heritage represent it not only as transcending the nations, states, and nationstates but as more or less 'off-ground ${ }^{21}$ in relation to its attachments to territories and locations, the transnationalistic view to heritage brings the nation back in, but with an emphasis on border-crossings of one or more states. Unlike the globalization discourse, transnationalism stresses the continuing significance of state borders, state policies, and national identities even as these are often perceived as transgressed by transnational communication and social practices. ${ }^{22}$ 
Could the European cultural heritage be defined as a transnational heritage, which acknowledges the national contexts of the heritage sites and objects but at the same time emphasizes their values as transcending the national and nationalist interpretations? Or is the European cultural heritage rather translocal? The idea of translocalism is more concretely grounded than transnationalism, as it locates the social and cultural relations in ground-level interactions that bypass state regulation without, however, being independent from it. In it, border-crossings are seen as important, and not just as crossings of national boundaries but as the crossing of borders between places that are linked to one another. As Arif Dirlik notes, translocalism undermines the boundaries of nation-states from 'below'. ${ }^{23}$

In both political and popular discourses, a European cultural heritage is often constructed from various national, regional, and local heritage sites, objects, symbols, and traditions which are then Europeanized, i.e., narrated as European in the media texts, popular history, tourism rhetoric, and political discourse of the EU. ${ }^{24}$ The creation of an iconography of European identity involves, as Gregory J. Ashworth and Brian Graham state, 'the manipulation of heritage, demanding the addition of new layers of meaning to built-environments and landscapes that are already fundamental symbols within national iconographies and narratives. Regional icons, already re-designated as national symbols, might further be subsumed within European heritage. ${ }^{25}$

Since the 19th century, nationalism has been closely intertwined with locality and regionality - national ideology has efficiently utilized local and regional alternation and characteristics in the production of national imagery, heritage, history, memory, and the nation itself. ${ }^{26}$ The national 'home' has commonly been molded from localities and regionalities. ${ }^{27} \mathrm{~A}$ similar process seems to take place in the production of European imagery, cultural heritage, and identity. ${ }^{28}$

\section{Defining a European Cultural Heritage in Scholarly Discussions}

Defining a European cultural heritage is never a neutral, objective, or value-free process. It means taking a stand on the idea of particularity; the significance of cultural exchange and interculturalism; and the views on sharing certain cultural values, understanding of the past, and communality that transcend the national level but are nonetheless not perceived as global or universal. Gerard Delanty emphasizes the impossibility to speak of a European cultural heritage without considering its political meaning: European cultural and political heritages cannot be separated. ${ }^{29}$ According to him, the movement from history to heritage embraces 'an evaluation of the past in order for the present to judge what legacy it should derive from history. The debate about European heritage is very much a question of identifying the cultural resources that might be relevant to the current challenges of European societies. ${ }^{30}$

In academic discussions, scholars have debated the possibility of a European cultural heritage, and in case such a heritage does exist, what could it be grounded 
upon. ${ }^{31}$ Critical scholars have asked what might be the European dimension of heritage that goes beyond the mere sum of national icons (while still promoting the nation), ${ }^{32}$ or questioned the possibility of common European commemoration and heritage practices due to the lack of a singular 'European people'. ${ }^{33}$ The nationstate still forms the fundamental ideological basis, territorialized political sphere, and institutionalized forum of practice for the fostering, preserving, and meaningmaking of cultural heritage.

Nevertheless, several scholars have recognized possible common grounds for perceiving and outlining a common European cultural heritage. Monica Sassatelli has fixed European heritage and identity to the idea of urbanity. ${ }^{34}$ Similarly, Gregory J. Ashworth and Brian Graham have taken up the discussion on European cities and their historical environment. ${ }^{35}$ According to them:

The problem is that there is relatively little evidence of Europeans focusing on the meaning of Europe. One possible exception might be articulated through 'Europe of the cities' (the environment in which most Europeans live, work and recreate) but specifically the 'Europe of the historic cities'. If pressed to define the content of what is typically European as opposed to appertaining to some other continent, it is likely that images of Florence, Bath and Heidelberg, of piazzas, boulevards and buildings, would be evoked among many who do not live in these particular environments, cities or even countries. In these senses a European heritage already exists in the European imagination $[--] .{ }^{36}$

Some scholars have fixed the idea of a European cultural heritage more specifically to architecture and architectural heritage. Gerard Delanty and Paul Jones write about the architectural styles and movements in Europe:

Architecture has thus been the quintessentially universalistic expression of civilization since all the great architectural designs - classical Greek, Romanesque, Renaissance, Gothic, Baroque, Rococo, Modernist - have been universalistic in their selfunderstanding and one of the most important expressions of European civilization transcending the particularism of its national cultures. ${ }^{37}$

In this view, universalistic discourse on heritage as an expression of civilization is amalgamated with the idea of European dimension of heritage creating an Eurocentric view to universality. 
In addition to (historical) urbanity, Gregory J. Ashworth and Brian Graham have approached the idea of a European cultural heritage by introducing two conceptual categories; 'the idea of European unity' and 'the unity of European ideas'. ${ }^{38}$ The heritage of 'the idea of European unity' is based on the recent narratives of building the European Union, its institutions, principles, and values, while the heritage of 'the unity of the European ideas' comprises ideas, values, and activities that are perceived to be continental rather than only national. Approaching heritage as being based on the idea of European unity, faces, however, insurmountable difficulties. As Ashworth and Graham note, 'there are just very few resources, whether buildings, events or personalities from the European past that could be used to shape such a European heritage in competition with the resources available at the national level. ${ }^{39}$ Also, the latter approach is problematic as the common 'continental' ideas, values, and activities in Europe are ambiguous and difficult to define.

Gregory J. Ashworth and Peter Howard have also called these two conceptual categories 'the heritage of the pan-European idea' and 'the heritage of panEuropean ideas'. In addition, they have broadened the view on the European dimension of heritage by taking into the discussion 'the heritage of European conflict' and European organizations as producers of heritage, because 'both above ideas for structuring a content of a European heritage founder on the dissonant nature of the European historical narrative'.$^{40}$ Particularly, the current heritage discourse of the EU fosters a pan-Europeanist, harmonious, and liberalist view on European heritage, although the actual history of Europe is filled with various illiberal views, violations of rights, and wars. ${ }^{41}$ Several other scholars, such as Gerard Delanty, have also emphasized conflicts and collective traumas as the common ground for shared European history and cultural heritage. ${ }^{42}$ This kind of point of view frames a European cultural heritage with sensitive, emotive, and problematic meanings commonly discussed in heritage studies with the concept of 'difficult heritage'. ${ }^{43}$

The idea of heritage has a close bond to places: heritage fixes identities and communal meanings to them. Particularly, the national, regional, and local dimensions of heritage easily intertwine with a place-identity. ${ }^{44}$ The diversity and cultural fragmentation of Europe challenges the link between the idea of common heritage and place-identity on a European scale. In fact, some scholars have perceived boundaries and borders as such as an inherent part of Europe's shared heritage. ${ }^{45}$ As Gabi Dolff-Bonekämper notes:

Why treat borders as heritage? Because Europe's nation states, and all the territorial and national units which preceded them, have left us a legacy of borders, borders old or recent (sometimes very recent), accepted or contested, fortified or open, threatening or all but invisible. These borders are lines, but only on the map. 
In reality, they stand for something bigger - border regions, which are also transit zones, places where cultures have met and mingled or, like many armies on the same ground, clashed. The architectural and landscape traces of the history made on those borders - the defences and gateways, the checkpoints and meeting places, the symbols of co-operation or rejection together form a heritage which we consider precious. Throughout Europe, they are places where shared memories converge. ${ }^{46}$

\section{Conclusions: Transcultural Understanding of Heritage}

Discussions on a European cultural heritage bring to the fore contradictory views on its foundations: according to some views, there exist shared cultural assets, sites, traditions, values, etc. in Europe, while some other views prefer to emphasize the idea of a European cultural heritage as founded upon the diversity of national, regional, and local particularities. In some discussions, a European cultural heritage is approached as an essentialist phenomenon, while in others it is outlined as a construction and a project - and often highly political in its nature.

How can we make sense of the idea of a European cultural heritage? If it is understood as a cosmopolitan heritage, it may become detached from placeidentities and territorial communities and turned into a privileged cultural capital viewed from 'above' and from a Eurocentric position. 'Vernacular' or 'rooted' cosmopolitan views could overcome the privileged nature of the idea of a European cultural heritage, but at the same time it would turn it into a subjectively understood cultural meaning belonging to the private sphere of people. The idea of a European cultural heritage as a transnational heritage draws on the meanings of heritage from the national level. It may narrow the idea of a European cultural heritage to the border crossings of cultural phenomena between or originating from the 'core' European countries, which have the most canonized and iconic heritage assets in the popular history of Europe. The translocal approach to a European cultural heritage broadens the idea of border crossings from the national to the local level, emphasizing micro-scale interconnectivity. A European cultural heritage could also be perceived as stemming from other kinds of border crossings and trans-border phenomena than just territorial ones. Defining a European cultural heritage as transcultural - a heritage that extends through different cultures in Europe - enables understanding it as a complex and multifaceted heritage which embraces elements penetrating not only different territorial layers but also various non-territorial cultural, social, intellectual, and ideological layers in Europe. 


\section{Notes}

1 Robert Shannan Peckham, 'The Politics of Heritage and Public Culture.' Rethinking Heritage. Cultures and Politics in Europe, ed. Robert Shannan Peckham (London: I.B.Tauris, 2003), 1.

2 E.g., Erik Hobsbawm, 'Introduction: Inventing Traditions.' The Invention of Tradition, eds. Erik Hobsbawm and Terrence Ranger (Cambridge: Cambridge University Press, 1983), 1-14; Peckham, 'The Politics of Heritage and Public Culture'; Thomas Risse, 'European Identity and the Heritage of National Culture.'

Rethinking Heritage. Cultures and Politics in Europe, ed. Robert Shannan Peckham (London: I.B.Tauris, 2003), 74-89.

${ }^{3}$ Peckham, 'The Politics of Heritage and Public Culture,' 2.

${ }^{4}$ John Henry Merryman, 'Two Ways of Thinking about Cultural Property.' The American Journal of International Law 80.4 (1986): 831-853.

${ }^{5}$ Ibid., 846.

${ }^{6}$ Maria T. Starzmann, 'Cultural Imperialism and Heritage Politics in the Event of Armed Conflict: Prospects for an 'Activist Archaeology'.' Archaeologies 4.3 (2008): 368-389; Barbara Kirshenblatt-Gimblett, 'World Heritage and Cultural Economics', Museum Frictions: Public Culture / Global Transformation, eds. Ivan Karp, Corinne A. Kratz, Lynn Szwaja and Tomás Ybarra-Frausto (Durham and London: Duke University Press, 2006), 161-202; Chiara Di Cesari, 'World Heritage and Mosaic Universalism. A View from Palestine.' Journal of Social Archaeology 10.3 (2010): 299-324.

${ }^{7}$ UNESCO, Convention Concerning the Protection of the World Cultural and Natural Heritage. 16 November 1972, viewed on 12 Jan 2015, http://whc.unesco.org/archive/convention-en.pdf.

${ }^{8}$ Merryman, 'Two Ways of Thinking about Cultural Property.'

${ }^{9}$ Derek Gillman, The Idea of Culture Heritage (Cambridge: Cambridge University Press, 2006), 49-55.

${ }^{10}$ Derek Gillman, The Idea of Culture Heritage.

11 Craig Calhoun, 'Cosmopolitan Europe and European Studies'. The Sage Handbook of European Studies, ed. Chris Rumford (Thousand Oaks: Sage Publications, 2009), 637-654.

${ }^{12}$ Bruce Robbins, 'Introduction Part I: Actually Existing Cosmopolitanism.' Cosmopolitics - Thinking and Feeling beyond the Nation, eds. Pheng Cheah and Bruce Robbins (Minnesota: Minnesota University Press, 1998), 1-19.

${ }^{13}$ Benita Parry, 'Overlapping Territories and Intertwined Histories: Edward Said‘s Postcolonial Cosmopolitanism.’ Edward Said: A Critical Reader, ed. Michael 
Sprinker (Oxford: Blackwell Publishers, 1992), 19-47; Benita Parry, 'The Contradictions of Cultural Studies.' Transition 53 (1991): 37-45.

${ }^{14}$ Homi K. Bhabha, 'Unsatisfied: Notes on Vernacular Cosmopolitanism.' Text and Nation: Cross-Disciplinary Essays on Cultural and National Identities, eds. Laura García-Moreno and Peter C. Pfeiffer (Columbia, SC: Camden House, 1996), 191-207; Homi K. Bhabha, 'The Vernacular Cosmopolitan.' Voices of the Crossing: The Impact of Britain on Writers from Asia, the Caribbean, and Africa, eds. Ferdinand Dennis and Naseem Khan (London: Serpent's Tail, 2000), 133-142.

${ }^{15}$ Kwame Anthony Appiah, The Ethics of Identity (Princeton: Princeton University Press, 2005).

${ }^{16}$ Zlatko Skrbis, Gavin Kendall and Ian Woodward, 'Locating Cosmopolitanism: Between Humanist Ideal and Grounded Social Category.' Theory Culture \& Society 21.6 (2004): 115-136; Jan Nederveen Pieterse, 'Emancipatory Cosmopolitanism: Towards an Agenda.' Development and Change 37.6 (2006): 1247-1257.

${ }^{17}$ Appiah, The Ethics of Identity.

${ }^{18}$ Pieterse, 'Emancipatory Cosmopolitanism: Towards an Agenda,' 1252.

${ }^{19}$ Ibid., 1253.

${ }^{20}$ Craig Calhoun, 'Cosmopolitanism and Nationalism.' Globalization and the State: Sociological Perspectives on the State of the State, ed. Willem Schinkel (Basingstoke: Palgrave Macmillan, 2009), 209-242.

${ }^{21}$ Concept used by Jean Chesneaux in relation to global economics. Jean Chesneaux, Brave Modern World: The Prospects for Survival (London: Thames \& Hudson 1992).

${ }^{22}$ Michael Peter Smith, Transnational Urbanism: Locating Globalization (Oxford: Blackwell Publishing, 2001), 3; Manuel Castells, The Power of Identity, The Information Age: Economy, Society and Culture Vol. II (Oxford: Blackwell, 1997). Theoretical discussions on various forms of transnationalisms, see e.g., Nina Glick Schiller and Georges Fouron, 'Transnational Lives and National Identities: The Identity Politics of Haitian Immigrants.' Transnationalism from Below, eds. Michael P. Smith and Luis E. Guarnizo (New Brunswick: Transaction Books, 1998), 130-161.

${ }^{23}$ Arif Dirlik, 'Transnationalism in Theory and Practice: Uses, Mis-Uses, Abuses.' ALAI, América Latina en Movimiento 17 Oct 2010, viewed 15 Jan 2015, http://alainet.org/active/42339\&lang=es

${ }^{24}$ Tuuli Lähdesmäki, 'Rhetoric of Unity and Cultural Diversity in the Making of European Cultural Identity.' International Journal of Cultural Policy 18.1 (2012): 59-75.

${ }^{25}$ Gregory J. Ashworth and Brian Graham, 'Heritage, Identity and Europe.' Tijdschrift voor Economische en Sociale Geografie 88.4 (1997): 382. 
26 Anssi Paasi, Territories, Boundaries and Consciousness. The Changing Geographies of the Finnish-Russian Border (Chichester: John Wiley \& Sons. 1996), 144-145; Maiken Umbach, 'The Vernacular International: Heimat, Modernism and the Global Market in Early Twentieth-Century Germany.' National Identities 4.1 (2002): 46.

${ }^{27}$ Alon Confino and Ajay Skaria, 'Viewed from the Locality: The Local, National and Global.’ National Identities 4.1 (2002): 5.

${ }^{28}$ Tuuli Lähdesmäki, 'The EU's Explicit and Implicit Heritage Politics.' European Societies 16.3 (2014): 401-421.

${ }^{29}$ Gerard Delanty. 'The European Heritage: History, Memory, and Time.' The Sage Handbook of European Studies, ed. Chris Rumford (London: Sage, 2009), 36. 30 Ibid.

${ }^{31}$ E.g., Gregory J. Ashworth and Peter J. Larkham (eds.) Building a New Heritage. Tourism, Culture and Identity in the New Europe (London: Routlegde, 1994).

32 E.g., Monica Sassatelli, 'The Logic of Europeanizing Cultural Policy.' Transcultural Europe. Cultural Policy in a Changing Europe, eds. Ulrike H. Meinhof and Anna Triandafyllidou (Basingstoke: Palgrave MacMillian, 2006), 29.

${ }^{33}$ E.g., Delanty, 'The European Heritage: History, Memory, and Time,' 37.

${ }^{34}$ Monica Sassatelli, Becoming Europeans. Cultural Identity and Cultural Policies (New York: Palgrave Macmillan, 2009).

${ }^{35}$ Ashworth and Graham, 'Heritage, Identity and Europe.'

${ }^{36}$ Ibid., 387.

37 Gerard Delanty and Paul R. Jones, 'European Identity and Architecture.' European Journal of Social Theory 5.4 (2002): 453-454.

${ }^{38}$ Ashworth and Graham, 'Heritage, Identity and Europe,' 383-384.

${ }^{39}$ Ibid., 383.

40 Peter Howard and Gregory J. Ashworth, European Heritage. Planning and Management (Exeter: Intellect Books, 1999), 69.

${ }^{41}$ See e.g., Gregory J. Ashworth and Peter J. Larkham, 'A Heritage for Europe: The Need, the Task, the Contribution.' Building a New Heritage. Tourism, Culture and Identity in the New Europe, eds. Gregory J. Ashworth and Peter J. Larkham (London: Routlegde, 1994), 4.

${ }^{42}$ Gerard Delanty, 'Models of European Identity: Reconciling Universalism and Particularism.’ Perspectives on European Politics and Society 3.3 (2002): 345-359; Marieke Kuipers and John Schofield, 'Lines of Tension.' Dividing Lines, Connecting Lines. Europe's Cross-Border Heritage, ed. Gabi Dolff-Bonekämper (Strasbourg: Council of Europe Publishing, 2004), 29-47.

43 Sharon Macdonald, Difficult Heritage. Negotiating the Nazi Past in Nuremberg and Beyond (New York: Routledge, 2009).

${ }^{44}$ Ashworth and Larkham, 'A Heritage for Europe.' 
45 Gabi Dolff-Bonekämper, 'Introduction.' Dividing Lines, Connecting Lines. Europe's Cross-Border Heritage, ed. Gabi Dolff-Bonekämper (Strasbourg: Council of Europe Publishing, 2004), 15.

${ }^{46}$ Ibid., 11.

\section{Bibliography}

Appiah, Kwame Anthony. The Ethics of Identity. Princeton: Princeton University Press, 2005.

Ashworth, Gregory J. and Brian Graham. 'Heritage, Identity and Europe.' Tijdschrift voor Economische en Sociale Geografie 88.4 (1997): 381-388.

Ashworth, Gregory J. and Peter J. Larkham. 'A Heritage for Europe: The Need, the Task, the Contribution.' Building a New Heritage. Tourism, Culture and Identity in the New Europe, edited by. Gregory J. Ashworth and Peter J. Larkham, 1-9. London: Routlegde, 1994.

Bhabha, Homi K. 'Unsatisfied: Notes on Vernacular Cosmopolitanism.' Text and Nation: Cross-Disciplinary Essays on Cultural and National Identities, edited by Laura García-Moreno and Peter C. Pfeiffer, 191-207. Columbia: Camden House, 1996.

. 'The Vernacular Cosmopolitan.' Voices of the Crossing: The Impact of Britain on Writers from Asia, the Caribbean, and Africa, edited by Ferdinand Dennis and Naseem Khan, 133-142. London: Serpent's Tail, 2000.

Calhoun, Craig. 'Cosmopolitanism and Nationalism.' Globalization and the State: Sociological Perspectives on the State of the State, edited by Willem Schinkel, 209-242. Basingstoke: Palgrave Macmillan, 2009.

- 'Cosmopolitan Europe and European Studies'. The Sage Handbook of European Studies, edited by Chris Rumford, 637-654. Thousand Oaks: Sage Publications, 2009.

Castells, Manuel. The Power of Identity, The Information Age: Economy, Society and Culture Vol. II. Oxford: Blackwell, 1997.

Chesneaux, Jean. Brave Modern World: The Prospects for Survival. London: Thames \& Hudson 1992. 
Confino, Alon and Ajay Skaria. 'Viewed from the Locality: The Local, National and Global.’ National Identities 4.1 (2002): 5-6.

Delanty, Gerard. 'Models of European Identity: Reconciling Universalism and Particularism.' Perspectives on European Politics and Society 3.3 (2002): 345-359.

- 'The European Heritage: History, Memory, and Time.' The Sage Handbook of European Studies, edited by Chris Rumford, 36-51. London: Sage, 2009.

Delanty, Gerard and Paul R. Jones. 'European Identity and Architecture.' European Journal of Social Theory 5.4 (2002): 453-466.

Di Cesari, Chiara. 'World Heritage and Mosaic Universalism. A View from Palestine.' Journal of Social Archaeology 10.3 (2010): 299-324.

Dirlik, Arif. 'Transnationalism in Theory and Practice: Uses, Mis-Uses, Abuses.' ALAI, América Latina en Movimiento, 17 Oct 2010. Viewed 15 Jan 2015. http://alainet.org/active/42339\&lang=es

Dolff-Bonekämper, Gabi. 'Introduction.' Dividing Lines, Connecting Lines. Europe's Cross-Border Heritage, edited by Gabi Dolff-Bonekämper, 11-16. Strasbourg: Council of Europe Publishing, 2004.

Gillman, Derek. The Idea of Culture Heritage. Cambridge: Cambridge University Press, 2006.

Hobsbawm, Erik. 'Introduction: Inventing Traditions.' The Invention of Tradition, edited by Erik Hobsbawm and Terrence Ranger, 1-14. Cambridge: Cambridge University Press, 1983.

Howard, Peter and Gregory J. Ashworth. European Heritage. Planning and Management. Exeter: Intellect Books, 1999.

Kirshenblatt-Gimblett, Barbara. 'World Heritage and Cultural Economics', Museum Frictions: Public Culture / Global Transformation, edited by Ivan Karp, Corinne A. Kratz, Lynn Szwaja and Tomás Ybarra-Frausto, 161-202. Durham and London: Duke University Press, 2006. 
Kuipers, Marieke and John Schofield. 'Lines of Tension.' Dividing Lines, Connecting Lines. Europe's Cross-Border Heritage, edited by Gabi DolffBonekämper, 29-47. Strasbourg: Council of Europe Publishing, 2004.

Lähdesmäki, Tuuli. 'Rhetoric of Unity and Cultural Diversity in the Making of European Cultural Identity.' International Journal of Cultural Policy 18.1 (2012): 59-75.

'The EU's Explicit and Implicit Heritage Politics.' European Societies 16.3 (2014): 401-421.

Macdonald, Sharon. Difficult Heritage. Negotiating the Nazi Past in Nuremberg and Beyond. New York: Routledge, 2009.

Merryman, John Henry. 'Two Ways of Thinking about Cultural Property.' The American Journal of International Law 80.4 (1986): 831-853.

Parry, Benita. 'The Contradictions of Cultural Studies.' Transition 53 (1991): 3745.

- 'Overlapping Territories and Intertwined Histories: Edward Said's Postcolonial Cosmopolitanism.' Edward Said: A Critical Reader, edited by Michael Sprinker, 19-47. Oxford: Blackwell Publishers, 1992.

Peckham, Robert Shannan. 'The Politics of Heritage and Public Culture.' Rethinking Heritage. Cultures and Politics in Europe, edited by Robert Shannan Peckham, 1-13. London: I.B.Tauris, 2003.

Pieterse, Jan Nederveen. 'Emancipatory Cosmopolitanism: Towards an Agenda.' Development and Change 37.6 (2006): 1247-1257.

Risse, Thomas. 'European Identity and the Heritage of National Culture.' Rethinking Heritage. Cultures and Politics in Europe, edited by Robert Shannan Peckham, 74-89. London: I.B.Tauris, 2003.

Robbins, Bruce. 'Introduction Part I: Actually Existing Cosmopolitanism.' Cosmopolitics - Thinking and Feeling beyond the Nation, edited by Pheng Cheah and Bruce Robbins, 1-19. Minnesota: Minnesota University Press, 1998. 
Sassatelli, Monica. 'The Logic of Europeanizing Cultural Policy.' Transcultural Europe. Cultural Policy in a Changing Europe, edited by Ulrike H. Meinhof and Anna Triandafyllidou, 24-42. Basingstoke: Palgrave MacMillian, 2006.

- Becoming Europeans. Cultural Identity and Cultural Policies. New York: Palgrave Macmillan, 2009.

Schiller, Nina Glick and Georges Fouron. 'Transnational Lives and National Identities: The Identity Politics of Haitian Immigrants.' Transnationalism from Below, edited by Michael P. Smith and Luis E. Guarnizo, 130-161. New Brunswick: Transaction Books, 1998.

Skrbis, Zlatko, Gavin Kendall and Ian Woodward. 'Locating Cosmopolitanism: Between Humanist Ideal and Grounded Social Category.' Theory Culture \& Society 21.6 (2004): 115-136.

Smith, Michael Peter. Transnational Urbanism: Locating Globalization. Oxford: Blackwell Publishing, 2001.

Starzmann, Maria T. 'Cultural Imperialism and Heritage Politics in the Event of Armed Conflict: Prospects for an 'Activist Archaeology'.' Archaeologies 4.3 (2008): 368-389.

Umbach, Maiken. 'The Vernacular International: Heimat, Modernism and the Global Market in Early Twentieth-Century Germany.' National Identities, 4.1 (2002): 45-68.

UNESCO, Convention Concerning the Protection of the World Cultural and Natural Heritage. 16 November 1972. Viewed on 12 Jan 2015. http://whc.unesco.org/archive/convention-en.pdf

Tuuli Lähdesmäki, PhD, DScoSci, is an Academy Research Fellow at the Department of Art and Culture Studies in the University of Jyväskylä, Finland. She conducts her research on the meanings and production of European cultural heritage in the EU heritage initiatives and policy discourses in the research projects 'European Cultural Heritage in the Making: Politics, Affects, and Agency (EUCHE)' funded by the Academy of Finland (SA274295) and 'Arts of Belonging: Cultural, Material, and Affective Aspects of Homing' funded by Kone Foundation. 